\title{
Aspidosperma (Apocynaceae) no estado de Mato Grosso do Sul, Brasil
} Aspidosperma (Apocynaceae) in Mato Grosso do Sul state, Brazil

\author{
David Johane Machate ${ }^{1,4}$, Flávio Macedo Alves $^{2}$ \& Maria Ana Farinaccio ${ }^{3}$
}

\begin{abstract}
Resumo
Aspidosperma compreende 55 espécies, das quais 41 ocorrem no Brasil. A maior riqueza está na região CentroOeste com 28 espécies. O presente trabalho teve como objetivo contribuir para o conhecimento da diversidade de Aspidosperma no Mato Grosso do Sul. Baseou-se na análise de amostras coletadas em 22 expedições de campo, visitas e consultas online aos herbários. No estado, o gênero está representado por 14 espécies. Aspidosperma quirandy e A. verbascifolium foram coletadas e descritas pela primeira vez no Mato Grosso do Sul. No presente estudo são apresentadas: chave de identificação para as espécies, descrição, distribuição geral e ecologia, dados de floração/frutificação, status de conservação e comentários taxonômicos.

Palavras-chave: biodiversidade, flora, sistemática.
\end{abstract}

\begin{abstract}
Aspidosperma comprises 55 species, 41 of them occurring in Brazil, with the greatest richness in the Midwest region, with 28 species. This study aimed to contribute with knowledge upon species diversity of Aspidosperma in Mato Grosso do Sul. The study was based on the analysis of samples collected in 22 field expeditions, herbaria visits and online consultations. In the state, the genus is represented by 14 species. Aspidosperma quirandy and A. verbascifolium were collected and described for the first time in Mato Grosso do Sul. We present identification key of the species, description, general distribution and ecology, flowering/fructification, conservation status, and taxonomic comments.

Key words: biodiversity, flora, systematics.
\end{abstract}

\section{Introdução}

Apocynaceae é constituída por ervas, subarbustos, arbustos, árvores e lianas, geralmente latescentes. Apresenta aproximadamente 400 gêneros e 5000 espécies (Endress et al. 2014; Rapini 2012). Dentre os gêneros, Aspidosperma Mart. é neotropical, ocorrendo desde o México até Argentina com exceção do Chile. O gênero tem maior riqueza na região Centro-Oeste do Brasil, com maior representação para estado de Mato Grosso com 23 espécies (BFG 2015). Aspidosperma é um gênero de grande importância econômica, sendo as espécies fornecedoras de madeira para construção civil e carpintaria, bem como tem espécies com potencial para arborização, paisagismo, reflorestamento (Lorenzi 1992, 1998) e são usadas também na medicina popular (Pereira et al. 2007).
Aspidosperma foi reconhecido e descrito por Martius (1824a, b) com cinco espécies: $A$. macrocarpon Mart., A. refractum Mart., A. bicolor Mart., A. pyrifolium Mart. e A. tomentosum Mart., sendo esta última a espécie tipo. A partir daí, vários trabalhos de revisão ampliaram o número de espécies de Aspidosperma, e.g., De Candolle (1844) reconheceu 18 espécies (nove novas); Müller (1860), 39 espécies (22 novas); Woodson (1951), 52 espécies (oito novas) e Marcondes-Ferreira \& Kinoshita (1996) reconheceram 45 espécies (três novas). A maioria destas espécies é de fácil reconhecimento, no entanto verifica-se que existem complexos de espécies, já que algumas delas apresentam grande variação morfológica, fato já foi mencionado em Woodson (1951).

\footnotetext{
${ }^{1}$ Universidade Federal de Mato Grosso do Sul, Prog. Pós-graduação em Biologia Vegetal, Centro de Ciências Biológicas e da Saúde, Cidade Universitária s.n., Lab. Sistemática Vegetal, 79070-900, Campo Grande, MS, Brasil.

${ }^{2}$ Universidade Federal de Mato Grosso do Sul, Centro de Ciências Biológicas e da Saúde, Cidade Universitária s.n., Lab. Sistemática Vegetal, 79070-900, Campo Grande, MS, Brasil.

${ }^{3}$ Universidade Federal de Mato Grosso do Sul, Ciências Biológicas, Câmpus do Pantanal, Unidade I, Av. Rio Branco 1270, Universitário, Herbário, 79304-902, Corumbá, MS, Brasil.

${ }^{4}$ Autor para correspondência: machatedavidjohanemachate@yahoo.com.br
} 
Estudos florísticos de cunho nacional e regional apontam número divergente de espécies de Aspidosperma no Mato Grosso do Sul. Dubs (1998) citou 10 para o estado espécies enquanto BFG (2015) indicaram 14 espécies. A flora de Mato Grosso do Sul é todavia pouco conhecida, pois trata-se de um dos estados brasileiros com um dos menores índices de coletas botânicas (Alves et al. 2016, no prelo), apontando para a grande necessidade de estudos na região para melhor conhecimento da biodiversidade. Por essa razão foi proposto o estudo taxonômico de Aspidosperma para Mato Grosso do Sul com objetivo de facilitar à identificação de um grupo de plantas relevante do ponto de vista florístico e econômico, além de contribuir para o conhecimento sobre a biodiversidade no estado.

\section{Material e Métodos}

O Mato Grosso do Sul localiza-se na região Centro-Oeste do Brasil (entre $71^{\circ} 24^{\prime} \mathrm{S}$ e $24^{\circ} 11^{\prime} \mathrm{S}$; $55^{\circ} 13^{\prime} \mathrm{W}$ e $\left.56^{\circ} 0,4^{\prime} \mathrm{W}\right)$, totaliza uma área de 357.145 $\mathrm{km}^{2}$. O estado apresenta formações vegetacionais de Cerrado, Chaco, Mata Atlântica, Amazônia, Caatinga e diferentes tipos de Florestas Estacionais (IBGE 1992). O clima é tropical ou temperado úmido, com verão quente e inverno seco (Peel et al. 2007).

Este estudo baseou-se nas análises das amostras depositadas nos herbários CGMS, COR, CPAP, MBM e UEC (acrônimos de acordo com Thiers, continuamente atualizado) e das coletas obtidas em 22 expedições realizadas entre abril de 2014 e setembro de 2015 no Mato Grosso do Sul, procurando abranger todas as formações vegetacionais do estado. A distribuição geral das espécies de Aspidosperma, que ocorrem no Mato Grosso do Sul, foi baseada em dados de coletas e análises de bancos de dados virtuais: Herbário Virtual Reflora, Jardim Botânico do Rio de Janeiro (RB), Lista de Espécies da Flora do Brasil, Species link, Tropicos ${ }^{\circledR}$, The New York Botanical Garden (NY).

O material botânico foi herborizado e as exsicatas depositadas no herbário CGMS, com duplicatas enviadas aos herbários CPAP, COR, MBM, NY e RB. Para a identificação das espécies utilizaramse bibliografias específicas para o gênero e.g., Martius (1824a, b), Müller (1860), Hassler (1913) e Woodson (1951). Sempre que possível os tipos nomenclaturais foram analisados. Os termos morfológicos: orientação dos lobos da corola foi de acordo com Font Quer (1985), padrões do ritidoma seguiram Ribeiro et al. (1999), tipos de inflorescências basearam-se em Gonçalves \& Lorenzi (2011) e aos demais caracteres foram de acordo com Radford et al. (1974).
A apresentação das espécies seguiu a ordem alfabética, as descrições e as características utilizadas na elaboração da chave de identificação foram baseadas nos táxons que ocorrem na área de estudo, exceto para as espécies que apresentaram material incompleto. A distribuição geográfica e os dados da floração/frutificação foram obtidos em campo e herbários. O status de conservação das espécies no estado baseou-se na observação de campo durante as coletas e para a classificação utilizou-se os critérios da IUCN (2011).

\section{Resultados e Discussão}

No Brasil, estudos florísticos específicos para a família Apocynaceae vêm contribuindo com o conhecimento do gênero Aspidosperma. Na região de Bauru, São Paulo, Koch \& Kinoshita (1999) identificaram quatro espécies; na Flora Fanerogâmica do estado de São Paulo Marcondes-Ferreira (2005) reconheceu 15 espécies; no Parque Nacional da Serra da Canastra, Minas Gerais, Morokawa et al. (2013) encontraram quatro espécies e no levantamento da diversidade da Flora do estado de Sergipe, foram reconhecidas três espécies de Aspidosperma (Koch 2013). Neste estudo reconhecemos 14 espécies de Aspidosperma no Mato Grosso do Sul, o mesmo número apontado por BFG (2015). No entanto, a composição de espécies foi diferente da apresentada aqui, já que esses autores incluem em sua listagem A. discolor e $A$. multiflorum, espécies que não foram encontradas nas expedições de coletas, nem nos herbários visitados e consultados. Dois novos registros para o estado foram incluídos, A. quirandy e $A$. verbascifolium.

Das 14 espécies de Aspidosperma no Mato Grosso do Sul, a maioria delas ocorre preferencialmente no Cerrado, algumas delas exclusivamente: $A$. macrocarpon, $A$. tomentosum, $A$. nobile e $A$. verbascifolium; além do Cerrado, também foram coletadas no Chaco florestado, Floresta Estacional Semidecidual e Mata ciliar no Pantanal: A. australe, na Floresta Estacional Semidecidual: A. parvifolium e outra naFloresta Estacional Semidecidual Submontana: A. polyneuron; na Floresta Estacional Decidual e Floresta Estacional Semidecidual Submontana: $A$. cuspa, A. cylindrocarpon, A. pyrifolium, A. quirandy e $A$. subincanum. Duas delas são endêmicas do Chaco: A. quebracho-blanco e A. triternatum. Verificouse, como resultado das expedições de coleta, que A. australe, A. cuspa, A. quebracho-blanco e A. subincanum formam populações com indivíduos mais agrupados, enquanto as demais espécies ocorrem com árvores mais isoladas. 
De acordo com IUCN (2011), as espécies de Aspidosperma no estado podem ser agrupadas através do status de conservação no critério criticamente em perigo (CR): A. parvifolium, A. polyneuron, $A$. quebracho-blanco e A. triternatum; em perigo (EM):
A. cuspa e A. cylindrocarpon; vulnerável (VU): $A$. macrocarpon e $A$. verbascifolium; quase ameaçado (NT): A. australe; e na categoria, pouco preocupante (LC) encontram-se: A. nobile, A. pyrifolium, A. quirandy, A. subincanum e A. tomentosum.

\section{Chave para identificação de espécies de Aspidosperma no Mato Grosso do Sul}

1. Folhas verticiladas; ápice foliar com espinho; látex incolor

2. Nervuras secundárias $\geq 15$ pares; folículos não mucronados; $23-26$ sementes por fruto

9. Aspidosperma quebracho-blanco

2'. Nervuras secundárias $\leq 12$ pares; folículos mucronados; 6-12 sementes por fruto

1'. Folhas alternas; ápice foliar sem espinho; látex branco ou vermelho 13. Aspidosperma triternatum

3. Látex vermelho; folículos elipsoides 5. Aspidosperma nobile

3'. Látex branco; folículos oblongos, achatados ou cilíndricos ou amplamente obovoides ou depressoobovoides ou depresso-ovoides

4. Folículos oblongos, achatados ou cilíndricos

5. Folículos achatados

5. Folículos cilíndricos

2. Aspidosperma cuspa

6. Pecíolos $<1,2 \mathrm{~cm}$ compr.; nervuras terciárias salientes; lobos da corola eretos, $<$ 0,15 cm compr.; folículos mucronados, $2-4$ sementes por fruto.

7. Aspidosperma polyneuron

6'. Pecíolos $\geq 1,3 \mathrm{~cm}$ compr.; nervuras terciárias impressas; lobos da corola sinistrorsos, $\geq 0,3 \mathrm{~cm}$ compr.; folículos não mucronados, 10-16 sementes por fruto.

3. Aspidosperma cylindrocarpon

4'. Folículos amplamente obovoides ou depresso-obovoides ou depresso-ovoides

7. Folículos amplamente obovoides

8. Ritidoma lenticelado; pecíolos glabros; flores glabras; folículo sem costas medianas e nervuras costais 1. Aspidosperma australe

8'. Ritidoma não lenticelado; pecíolos pubescentes a glabrescentes; flores seríceas; folículo com costas medianas e nervuras costais ......6. Aspidosperma parvifolium

7'. Folículos depresso-obovoides ou depresso-ovoides

9. Folículos depresso-obovoides 8. Aspidosperma pyrifolium

9'. Folículos depresso-ovoides

10. Folículos sem costas medianas, não lenticelados

11. Lâminas foliares $\leq 18 \mathrm{~cm}$ compr.; inflorescência dicásio; ovário velutino; 11-17 sementes por fruto 4. Aspidosperma macrocarpon

11'. Lâminas foliares $\geq 19 \mathrm{~cm}$ compr.; inflorescência pleiocásio; ovário glabro; 20-22 sementes por fruto 14. Aspidosperma verbascifolium

10'. Folículos com costas medianas, lenticelados

12. Ritidoma não suberoso, fissurado com cristas planas interrompidas por fissuras transversais; pecíolos $\geq 2 \mathrm{~cm}$ compr.; folhas com venação broquidódroma, frutos mucronados .......11. Aspidosperma subincanum

12'. Ritidoma suberoso, fissurado com cristas convexas; pecíolos $\leq 1 \mathrm{~cm}$ compr., folhas com venação craspedódroma ou semi-craspedódroma, frutos não mucronados

13. Venação craspedódroma; inflorescência subterminal; lobos da corola dextrorsos 12. Aspidosperma tomentosum

13'. Venação semi-craspedódroma; inflorescência terminal; lobos da corola sinistrorsos 10. Aspidosperma quirandy 
1. Aspidosperma australe Müll. Arg., Fl. Bras. 6(1): 58.1860.

Fig. 1a,b

Árvores, 5-30 m alt.; tronco verde a cinzento; ritidoma não suberoso, lenticelado, raramente fissurado; látex branco. Râmulos alternos, verdes a cinzentos, não suberosos, lenticelados, não fissurados, pubescentes a glabrescentes. Filotaxia alterna, pecíolos 1,7-5,4 cm compr., glabros; lâminas elípticas 3,5-12,7 × 2,6-6 cm, pubescentes a glabrescentes, base cuneada, assimétrica, ápice agudo a cuneado sem espinho, venação broquidódroma, nervuras secundárias 9-26, nervuras terciárias impressas. Inflorescência pleiocásio, terminal ou subterminal 1,9-3,4 cm compr., serícea; pedúnculo 0,8-1,9 cm compr.; pedicelo $0,3-0,5 \mathrm{~cm}$ compr. Flores $0,6-0,8 \mathrm{~cm}$ compr., externamente glabras; lacínias do cálice 0,19-0,24 cm compr., internamente seríceos; corola branca a amarelada; tubo 0,4-0,6 cm compr., diâmetro $0,17-0,19 \mathrm{~cm}$, internamente tomentosa, fendas no terço superior do tubo; lobos da corola $0,24-0,25 \times 0,21-0,22 \mathrm{~cm}$, ovais, eretos; anteras 0,08-0,14 cm compr.; filete 0,2-0,4 mm compr.; ovário ovoide $0,08-0,14 \mathrm{~cm}$ compr., tomentoso; estilete 0,1-0,2 cm compr.; cabeça estilar 0,2-0,4 mm compr., oblonga a globosa, glabra. Folículos verdes a acastanhados, amplamente obovoides 4,3-6,2 × 3,2-3,6 cm, costas medianas e nervuras costais ausentes, não mucronados, lenticelados, velutinos a pubescentes; pedúnculo 1,5-3,4 cm compr., lenticelado, glabro. Sementes castanhas 9-13 por fruto, amplamente elípticas a ovadas 3-4 $\times 2-3 \mathrm{~cm}$; núcleos elípticos a amplamente elípticos 2-2,5 × 1,6-1,9 cm de diâm., predominantemente excêntricos.

Material examinado selecionado: Corumbá, Fazenda São Bento, 6.VIII.2014, fl. e fr., D.J. Machate et al. 25 (CGMS).

Ocorre em Corumbá, Coxim, Ladário e Porto Murtinho; coletado no Cerrado, Chaco florestado, Floresta Estacional Semidecidual e Mata ciliar no Pantanal (tolerando inundações esporádicas) em solo arenoso, entre 90-143 m de altitude. Com flores em agosto, outubro e novembro e frutos de junho a novembro. Espécie quase ameaçada (NT) (IUCN 2011).

Pode ser confundida com A. parvifolium por apresentar frutos amplamente obovoides e não mucronados. Porém, $A$. australe difere desta por exibir ritidoma lenticelado, frutos sem costas medianas e nervuras costais (versus ritidoma não lenticelado, frutos com costas medianas e nervuras costais em $A$. parvifolium).
2. Aspidosperma cuspa (Kunth) S.F. Blake ex Pittier, Man. P1. Usual. Venez. 110. 1926.

Fig. 1c,d

Árvores ou arvoretas, 1-8 m alt.; tronco cinzento a castanho; ritidoma não suberoso, lenticelado, não fissurado; látex branco. Râmulos alternos, cinzentos, não suberosos, lenticelados, não fissurados, pubescentes a glabrescentes. Filotaxia alterna, pecíolos 0,4-0,7 cm compr., pubescentes; lâminas elípticas a obovais 2,6-10,5 $\times 1,6-5 \mathrm{~cm}$, seríceas a pubescentes, base aguda a cuneada, ápice agudo, cuneado a retuso sem espinho, venação broquidódroma, nervuras secundárias 19-30, nervuras terciárias impressas. Inflorescência dicásio, axilar ou subterminal 1-4 cm compr., tomentosa; pedúnculo 0,3-3,7 cm compr.; pedicelo 0,1-0,2 cm compr. Flores 0,3-0,4 cm compr., externamente tomentosas a glabrescentes, internamente glabras; lacínias do cálice $0,1-0,2 \mathrm{~cm}$ compr.; corola branca a acastanhada; tubo 0,36-0,4 cm compr., diâmetro $0,12-0,15 \mathrm{~cm}$, fendas na metade do tubo; lobos da corola $0,09-0,12 \times 0,1 \mathrm{~cm}$, obovais, eretos; anteras $0,1-0,13 \mathrm{~cm}$ compr.; filete $0,3-0,6 \mathrm{~mm}$ compr.; ovário ovoide $0,5-0,8 \mathrm{~mm}$ compr., glabro; estilete 0,1-0,6 mm compr.; cabeça estilar 0,2-0,3 mm compr., oblado, pubescente. Folículos acastanhados, oblongos, achatados 2,6-3,9 $\times$ $1,4-1,8 \mathrm{~cm}$, costas medianas presentes, nervuras costais ausentes, mucronados, lenticelados, seríceos a glabrescentes; pedúnculo 0,6-0,9 cm compr., lenticelado, seríceo a glabrescente. Sementes castanhas $1-4$ por fruto, elípticas 2,7-3,5 × 1,1-1,4 cm; núcleos elípticos 1,4-1,8 $\times 0,9-1,3 \mathrm{~cm}$ diâm., excêntricos.

Material examinado selecionado: Terenos, Fazenda Modelo (Embrapa), 2.XII.2005, fl., A. Pott et al. 13091 (CGMS); Jaraguari, Furna de Dionísio, 14.VIII.2014, D.J. Machate \& J.R. Fabri. 144 (CGMS).

Ocorre em Aquidauana, Corumbá, Jaraguari, Nioaque e Terenos. A espécie foi coletada na Floresta Estacional Decidual e Floresta Estacional Semidecidual Submontana, em solo arenoso e litólico, entre 85-220 m de altitude. Com flores em junho, novembro e dezembro e frutos de março a agosto. Espécie em perigo (EN) pelos critérios A1(acd) e B2(bi) (IUCN 2011).

Dentre as três espécies com folículos oblongos que ocorrem no Mato Grosso do Sul, A. cuspa é facilmente reconhecida, pois é a única que tem os frutos achatados. Vale a pena destacar que esta espécie têm os menores frutos no gênero com 2,6 a 3,9 cm de comprimento. 
3. Aspidosperma cylindrocarpon Müll. Arg., Fl. Bras. 6(1): 54. 1860.

Fig. 1e

Árvores ou arvoretas, 3-15 m alt.; tronco cinzento a castanho; ritidoma suberoso, não lenticelado, fissurado com cristas agudas, interrompidas por fissuras transversais; látex branco. Râmulos alternos, cinzentos, não suberosos, lenticelados, não fissurados, glabrescentes. Filotaxia alterna, pecíolos 1,3-2,5 cm compr., glabras; lâminas elípticas 3,8-9,1 $\times 1,8-4,3 \mathrm{~cm}$, seríceas, base aguda a cuneada, ápice agudo a acuminado sem espinho, venação broquidódroma, nervuras secundárias 20-23, nervuras terciárias impressas. Inflorescência dicásio, terminal ou subterminal 3,3-4,1 cm compr., tomentosa; pedúnculo 2,2-2,9 cm compr.;
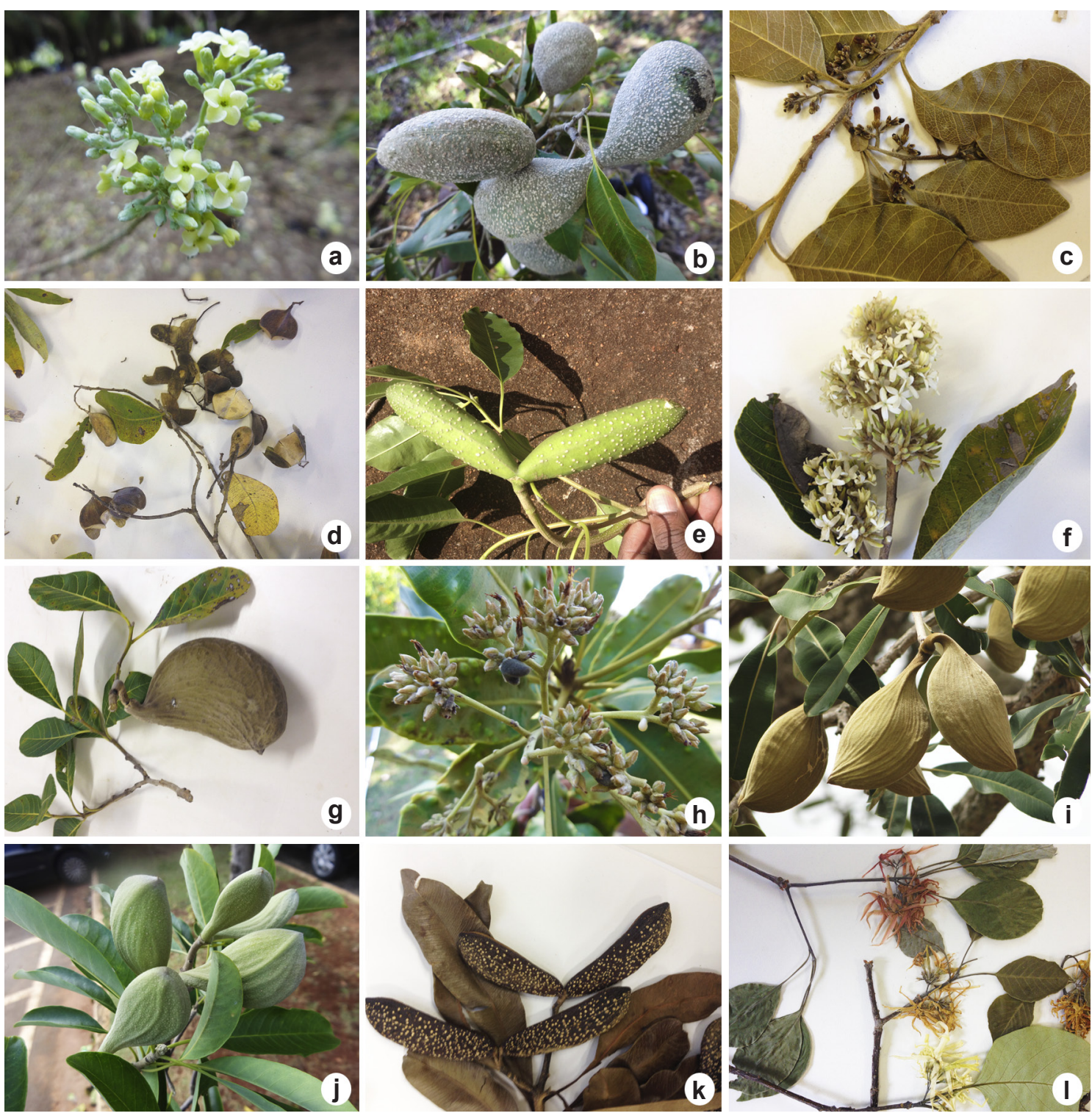

Figura 1 - a-b. Aspidosperma australe - a. inflorescência; b. frutos. c-d. A. cuspa - c. ramos com inflorescência; d. ramos com frutos e sementes. e. A. cylindrocarpon - ramos com frutos. f-g. A. macrocarpon-f. inflorescência; g. ramos com fruto. h-i. $A$. nobile -h. inflorescência; i. frutos. j. A. parvifolium-frutos. k. A. polyneuron-frutos. 1. A. pyrifolium-ramos com inflorescência. Figure 1 - a-b. Aspidosperma australe - a. inflorescence; b. fruits. c-d. A. cuspa -c. inflorescence branch; d. fruit and seed branch. e. A. cylindrocarpon - fruit branch. f-g. A. macrocarpon - f. inflorescence; g. fruit branch. h-i. A. nobile - h. inflorescence; i. fruits. j. A. parvifolium - fruits. k. A. polyneuron - fruits. 1. A. pyrifolium - inflorescence branch. 
pedicelo 0,16-0,24 cm compr. Flores 0,43-0,53 cm compr., externamente tomentosas; lacínias do cálice 0,06-0,1 cm compr., internamente glabros; corola branca a amarelada; tubo $0,17-0,22 \mathrm{~cm}$ compr., diâmetro $0,1 \mathrm{~cm}$, internamente tomentoso, fendas no terço inferior do tubo; lobos da corola $0,3-0,34 \times 0,07-0,08 \mathrm{~m}$, internamente glabros, oblongos, sinistrorsos; anteras 0,45-0,54 mm compr.; filete $0,04-0,06 \mathrm{~mm}$ compr.; ovário ovoide, 0,5-0,8 mm compr., tomentoso; estilete 0,1-0,2 mm compr.; cabeça estilar 0,15-0,16 mm compr., oblonga, glabra. Folículos castanhos, oblongos, cilíndricos, 5-7 × 1-3 cm, costas medianas presentes, inconspícuas, nervuras costais ausentes, não mucronados, lenticelados, seríceos; pedúnculo 13,8-14,5 cm compr., lenticelado, glabro. Sementes castanhas 10-16 por fruto, obovadas, $1,5-2,1 \times 0,6-0,7 \mathrm{~cm}$; núcleos ovados a elípticos, $0,8-1,5 \times 0,4-0,7 \mathrm{~cm}$, diâm., excêntricos.

Material examinado selecionado: Corumbá, Fazenda Band'alta, trilha 3, 12.IX.2007, fl., E.M. Jesus et al. 190 (CPAP).

Material examinado complementar: SÃO PAULO: Campinas, Unicamp, 12.V.2015, fr., D.J. Machate \& W. Marcondes-Ferreira 133 (CGMS).

Ocorre em Corumbá e Terenos; na Floresta Estacional Decidual e Floresta Estacional Semidecidual Submontana, em solo argiloso e arenoso, entre 90-154 $\mathrm{m}$ de altitude. Com flores em setembro e frutos em setembro, novembro e dezembro. Espécie em perigo (EN) pelos critérios A1(acd) e B2(bi) (IUCN 2011).

Pode ser confundida com $A$. polyneuron por apresentar frutos oblongos, cilíndricos e lenticelados. Porém, A. cylindrocarpon difere desta por ter pecíolos 1,6 a 2,5 cm de comprimento, lâminas com nervuras terciárias impressas, folículos não mucronados e 10 a16 sementes por fruto (versus pecíolos 0,7 a $1,2 \mathrm{~cm}$ de comprimento, lâminas com nervuras terciárias salientes, folículos mucronados e 2 a 4 sementes por fruto em $A$. polyneuron).

4. Aspidosperma macrocarpon Mart., Flora 7(1, Beil. 4): 136. 1824.

Fig. 1f,g

Arvoretas, 1-5 m alt.; tronco cinzento; ritidoma suberoso, não lenticelado, fissurado com cristas convexas, longitudinalmente descontínuas; látex branco. Râmulos alternos, cinzentos a amarelos, não suberosos, não lenticelados, não fissurados, pubescentes a vilosos. Filotaxia alterna, pecíolos 1,4-3 cm compr., vilosos; lâminas elípticas a obovais $8-18 \times 5-8 \mathrm{~cm}$, abaxialmente vilosas, adaxialmente pubescentes, base aguda, ápice agudo, cuneado a retuso sem espinho, venação craspedódroma, nervuras secundárias 10-13, nervuras terciárias impressas. Inflorescência dicásio, axilar ou terminal 3,8-6,5 $\mathrm{cm}$ compr., tomentosa; pedúnculo $0,1-0,5 \mathrm{~cm}$ compr.; pedicelo 0,2-0,3 cm compr. Flores 1,1-1,9 cm compr., externamente tomentosas; lacínias do cálice $0,4 \mathrm{~cm}$ compr., internamente tomentosos; corola branca; tubo 0,3-0,4 cm compr., diâmetro 0,25-0,27 cm, internamente pubescente, fendas no terço inferior do tubo; lobos da corola $0,8-1,2$ $\times 0,3 \mathrm{~cm}$, oblongos, eretos; anteras $0,18-0,19 \mathrm{~cm}$ compr.; filete $0,6 \mathrm{~mm}$ compr.; ovário oblongo 0,1-0,12 cm compr., velutino; estilete 0,16-0,18 cm compr.; cabeça estilar $0,7-0,8 \mathrm{~mm}$ compr., oblonga, glabra. Folículos cinzentos, depressoovoides $12-15,2 \times 8,2-8,4 \mathrm{~cm}$, costas medianas e nervuras costais ausentes, mucronados, não lenticelados, tomentosos; pedúnculo 2,6-2,9 cm compr., fissurado, glabro. Sementes castanhas 11-17 por fruto, predominantemente circulares 7,1-7,9 de diâm.; núcleos circulares 4,8-5,8 cm diâm., concêntricos.

Material examinado selecionado: Campo Grande, RPPN-UFMS, 28.X.2014, fl. e fr., D.J. Machate \& F.F. Júnio 42 (CGMS).

Ocorre em Campo Grande, Camapuã e Bandeirantes; no Cerrado, em solo arenoso, entre 256-545 m de altitude. Com flores de agosto a outubro e fruto em fevereiro, setembro e outubro. Espécie vulnerável (VU) pelos critérios A1(acd) e D2 (IUCN 2011).

Pode ser confundida com $A$. verbascifolium por apresentar frutos cinzentos, depresso-ovoides, costas medianas e nervuras costais ausentes, não lenticelados e tomentosos. Porém, $A$. macrocarpon difere desta por exibir râmulos não suberosos, lâminas foliares menores ou iguais a $18 \mathrm{~cm}$ de comprimento e ovário velutino (versus râmulos suberosos, lâminas foliares maiores ou iguais a $19 \mathrm{~cm}$ de comprimento e ovário glabro em $A$. verbascifolium). Vale a pena destacar que essas espécies apresentam os maiores frutos no gênero com 12 a $20 \mathrm{~cm}$ de comprimento.

5. Aspidosperma nobile Müll. Arg., Fl. Bras. 6(1): 44. 1860.

Fig. 1h,i

Árvores ou arvoretas, 4-10 m alt.; tronco cinzento a amarelo; ritidoma suberoso, não lenticelado, fissurado com cristas planas, interrompidas por fissuras transversais; 
látex vermelho. Râmulos alternos, verdes a amarelos, suberosos, não lenticelados, fissurados longitudinalmente e tomentosos. Filotaxia alterna, pecíolos 1,8-3,3 cm compr.; lâminas oblongas 9,5-16 × 3,7-5,9 cm, tomentosas, base aguda, ápice agudo a cuneada sem espinho, venação craspedódroma, nervuras secundárias 30-53, nervuras terciárias impressas. Inflorescência pleiocásio, terminal ou subterminal 12,1-14,6 cm compr., tomentosa; pedúnculo 10,6-13,1 cm compr.; pedicelo $0,2-0,3 \mathrm{~cm}$ compr. Flores $1,2-1,3$ cm compr., externamente tomentosas; lacínias do cálice $0,2-0,3 \mathrm{~cm}$ compr., internamente vilosos; corola castanha a amarelada; tubo $0,46-0,53$ cm compr., diâmetro $0,1-0,2 \mathrm{~cm}$, internamente seríceo, fendas no terço inferior do tubo; lobos da corola $0,4-0,5 \times 0,04-0,05 \mathrm{~cm}$, internamente glabros, lanceolados, sinistrorsos; anteras $0,7-0,8 \mathrm{~mm}$ compr.; filete $0,1-0,3 \mathrm{~mm}$ compr.; ovário ovoide $0,7 \mathrm{~mm}$ compr., glabro; estilete $0,1-0,2 \mathrm{~mm}$ compr.; cabeça estilar $0,4-0,5 \mathrm{~mm}$ compr., oblonga, glabra. Folículos castanhos a amarelados, elipsoides 10,7-16,9 × 5,3-8,1 cm, costas medianas e nervuras costais presentes, mucronados, não lenticelados, tomentosos; pedúnculo 5,6-9,1 cm compr., lenticelado, tomentoso. Sementes brancas a acastanhadas 10-22 por fruto, amplamente elípticas 5,4-7,2 $\times 4,5-6,1 \mathrm{~cm}$; núcleos oblados a circulares 2,2-2,4 × 1,9-2 cm diâm., predominantemente concêntricos.

Material examinado selecionado: Campo Grande, em frente ao laboratório da Química, 8.IX.2014, fl., D.J. Machate \& F.F. Júnio 40 (CGMS); Piraputanga, ao longo da estrada para o cerradinho da Universidade Estadual de Mato Grosso do Sul, 25.XI.2014, fr., D.J. Machate et al. 75 (CGMS).

Ocorre em Aquidauana, Bodoquena, Campo Grande, Jardim, Nioaque e Nova Alvorada; no Cerrado, em solo arenoso, entre 259-450 m de altitude. Com flores em setembro e frutos em novembro e dezembro. Espécie pouco preocupante (LC) (IUCN 2011).

Aspidosperma nobile é facilmente reconhecida na área de estudo, por apresentar látex vermelho, râmulos suberosos, fissurados longitudinalmente e tomentosos, folhas oblongas, tomentosas, ápice agudo a cuneada, inflorescência pleiocásio, terminal ou subterminal, tomentosa, com flores tomentosas, lobos da corola lanceolados e sinistrorsos, frutos elipsoides com costas medianas e nervuras costais, mucronados, tomentosos e contém 10 a 22 sementes por fruto.
6. Aspidosperma parvifolium A. DC., Prodr. 8: 398. 1844.

Fig. $1 \mathrm{j}$

Árvores ou arvoretas, 3-20 m alt.; tronco cinzento; ritidoma não suberoso, não lenticelado, não fissurado; látex branco. Râmulos alternos, castanhos, não suberosos, lenticelados, não fissurados, pubescentes a glabrescentes. Filotaxia alterna, pecíolos 1,2-3,6 cm compr.; lâminas elípticas 5,5-11,4 × 2-3,6 cm, pubescentes ou glabrescentes, base aguda a cuneada, ápice cuneado sem espinho, venação broquidódroma, nervuras secundárias 16-24, nervuras terciárias impressas. Inflorescência pleiotirso, terminal ou subterminal 3,8-4,1 cm compr., serícea; pedúnculo 0,5-0,6 $\mathrm{cm}$ compr.; pedicelo $0,1-0,2 \mathrm{~cm}$ compr. Flores 0,45-0,52 cm compr., seríceas; lacínias do cálice 0,1-0,2 cm compr., internamente seríceos; corola branca; tubo $0,4-0,5 \mathrm{~cm}$ compr., diâmetro $0,1 \mathrm{~cm}$, internamente pubescente, fendas na metade do tubo; lobos da corola $0,1-0,2 \times 0,03-0,07 \mathrm{~cm}$, ovais, eretos; anteras $0,1 \mathrm{~cm}$ compr.; filete $0,3-0,6$ mm compr.; ovário ovoide $0,6-0,9 \mathrm{~mm}$ compr., tomentoso; estilete $0,7-1 \mathrm{~cm}$ compr.; cabeça estilar 0,4-0,5 mm compr., oblonga, glabra. Folículos cinzentos, amplamente obovoides 4,3-5,6 × 2,8-3,1 $\mathrm{cm}$, costas medianas e nervuras costais presentes, não mucronados, não lenticelados, tomentosos; pedúnculo 1,6-4,7 cm compr., lenticelado, velutino a pubescente. Sementes castanhas 7-9 por fruto, elípticas a amplamente elípticas 2,9-3 × 1,7-2,5 $\mathrm{cm}$; núcleos elípticos a amplamente elípticos 1,7-1,8 × 1,2-1,5 cm diâm., concêntricos.

Material examinado selecionado: Campo Grande, Parque do Prosa, 11.VII.1993, fr., U.M. Resende 6858 (CGMS).

Material examinado complementar: BRASIL, SÃO PAULO: Campinas, Unicamp, 12.V.2015, fr., D.J. Machate \& W. Marcondes-Ferreira 135 (CGMS); PARAGUAY, 30.X.1978, fl., L. Bernardi et al. 18287 (MBM).

Ocorre em Anaurilândia, Campo Grande e Jardim; no Cerrado e na Floresta Estacional Semidecidual, em solo arenoso, entre 234-458 m de altitude. Com frutos em junho, julho e setembro. Espécie criticamente em perigo (CR) pelos critérios A1 (acd) e D (IUCN 2011).

Pode ser confundida com A. australe por apresentar frutos amplamente obovoides e não mucronados. Porém, A. parvifolium difere desta por exibir ritidoma não lenticelado, frutos com costas medianas e nervuras costais (versus ritidoma lenticelado, frutos sem costas medianas e nervuras costais em A. australe). 
7. Aspidosperma polyneuron Müll. Arg., Fl. Bras. 6(1): 57.1860.

Fig. $1 \mathrm{k}$

Árvores ou arvoretas, 3-18 m alt.; tronco cinzento a castanho; ritidoma suberoso, não lenticelado, fissurado com cristas planas, interrompidas por fissuras transversais; látex branco. Râmulos alternos, cinzentos, não suberosos, lenticelados, não fissurados, seríceos a pubescentes. Filotaxia alterna, pecíolos $0,7-1,2$ cm compr., glabros; lâminas elípticas a obovais $6,6-10,3 \times 3,7-4,2 \mathrm{~cm}$, abaxialmente pubescentes ou glabrescentes, adaxialmente glabras, base aguda a cuneada, ápice cuneado a retuso sem espinho, venação broquidódroma, nervuras secundárias 21-44, nervuras terciárias salientes. Inflorescência pleiocásio, terminal 1,5-2,4 cm compr., serícea; pedúnculo 1,2-1,4 cm compr.; pedicelo $0,2-0,3 \mathrm{~cm}$ compr. Flores $0,4-0,5 \mathrm{~cm}$ compr., seríceas; lacínias do cálice $0,1-0,2 \mathrm{~cm}$ compr.; corola branca a amarelada; tubo $0,3-0,5$ cm compr., diâmetro $0,2 \mathrm{~cm}$, fendas na metade do tubo; lobos da corola $0,08-0,12 \times 0,04-0,08 \mathrm{~cm}$, internamente pubescentes, ovados, eretos; anteras $0,7-0,8 \mathrm{~mm}$ compr.; filete $0,12-0,14 \mathrm{~mm}$ compr.; ovário ovoide $0,7-0,8 \mathrm{~mm}$ compr., tomentoso; estilete $0,5-0,8 \mathrm{~mm}$ compr.; cabeça estilar $0,3-0,5$ mm compr., oblonga, glabra. Folículos castanhos, oblongos, cilíndricos 3,8-4,7 ×0,1 cm, costas medianas presentes, nervuras costais ausentes, mucronados, lenticelados, glabros; pedúnculo 1,6-2 cm compr., não lenticelado, seríceo. Sementes castanhas 2-4 por fruto, estritamente oblongas 2,5-3,7 × 8-9 cm; núcleos obtrulados $0,9-1,3 \times 1 \mathrm{~cm}$, apicais.

Material examinado: Amambaí, 1979, fr., W.G. Garcia 13836 (UEC).

Material Complementar examinado: VENEZUELA. ZULIA: Mara, Carichuano de Corpozulia, 30.V.1980, fl., J.A. Steyermark et al. 122902 (MBM).

Ocorre em Amambaí e Campo Grande; no Cerrado e Floresta Estacional Semidecidual Submontana, solo arenoso e litólico, em 450-470 $\mathrm{m}$ de altitude. Com frutos provavelmente em maio ou junho. Espécie em perigo pelos critérios $\mathrm{A} 1$ (acd) e 2(cd). Porém, para a área de estudo, a espécie está criticamente em perigo (CR) pelos critérios A1(acd) e D (IUCN 2011).

Pode ser confundida com A. cylindrocarpon por apresentar frutos oblongos, cilíndricos e lenticelados. Porém, A. polyneuron difere desta por ter pecíolos 0,7 a $1,2 \mathrm{~cm}$ de comprimento, lâminas com nervuras terciárias salientes, folículos mucronados e 2 a 4 sementes por fruto (versus pecíolos 1,6 a 2,5 cm de comprimento, lâminas com nervuras terciárias impressas, folículos não mucronados e 10 a16 sementes por fruto em A. cylindrocarpon).

8. Aspidosperma pyrifolium Mart., Flora 7(1, Beil. 4): 136. 1824. Figs. 11; 2a

Árvores ou arvoretas, 3-15 m alt.; tronco cinzento; ritidoma não suberoso, lenticelado, não fissurado; látex branco. Râmulos opostos, castanhos, não suberosos, lenticelados, não fissurados, seríceos ou glabrescentes. Filotaxia alterna, pecíolos 1-3,3 cm compr., tomentosos a pubescentes; lâminas obovais 5,3-8,8 × 4,2-7,2 $\mathrm{cm}$, abaxialmente seríceas a pubescentes, adaxialmente tomentosas; base obtusa a cuneada, ápice agudo a cuneado sem espinho, venação broquidódroma, nervuras secundárias 10-19, nervuras terciárias impressas. Inflorescência dicásio, subterminal 2,4-3,4 cm compr., tomentosa; pedúnculo $1 \mathrm{~cm}$ compr.; pedicelo $0,3 \mathrm{~cm}$ compr. Flores $0,2-0,3 \mathrm{~cm}$ compr., externamente tomentosas; lacínias do cálice 0,1-0,4 cm compr., internamente glabros; corola branca a amarelada; tubo $0,45-0,52 \mathrm{~cm}$ compr., diâmetro 0,17-0,19 cm, internamente tomentoso, fendas na metade do tubo; lobos da corola 1,8-2,5 $\times 0,2-0,4 \mathrm{~cm}$, internamente glabros, lanceolados, dextrorsos; anteras $0,09-0,11 \mathrm{~cm}$ compr.; filete 0,5-0,6 mm compr.; ovário ovoide $0,08-0,1 \mathrm{~cm}$ compr., glabro; estilete $0,17-0,19 \mathrm{~cm}$ compr.; cabeça estilar 0,3-0,6 mm compr., elíptica, pubescente. Folículos castanhos, depressoobovoides 5-6,3 × 3-3,5 cm, costas medianas inconspícuas presentes, não mucronados, lenticelados, pubescentes; pedúnculo 1,6-2,3 cm compr., lenticelado, glabro. Sementes castanhas 3-4 por fruto, obovadas $3,1-4,2 \times 2,3-2,7 \mathrm{~cm}$; núcleos amplamente elípticos a circulares 1,3-1,9 $\times 1,3-1,6 \mathrm{~cm}$ diâm., concêntricos.

Material examinado selecionado: Corumbá, Morro Bocaina, 1.I.2002, fr., N.R. Bueno et al. 34 (COR); Ladário, Fazenda Uruba, Lote 54, 5.X.2012, fl., P.P. Oliveira et al. 155 (COR).

Ocorre em Bonito, Corumbá, Ladário e Porto Murtinho; na Floresta Estacional Decidual e Floresta Estacional Semidecidual, em solo arenoso e litólico, entre 153-159 m de altitude. Com flores em outubro e frutos em janeiro, fevereiro e junho. Espécie pouco preocupante (LC) (IUCN 2011).

Aspidosperma pyrifolium é facilmente reconhecida por apresentar râmulos opostos, 
folhas obovais, base obtusa a cuneada, ápice agudo a cuneado, inflorescência dicásio, subterminal, tomentosa, flores externamente tomentosas, lobos quatro a cinco vezes mais longos que o tudo da corola, cabeça estilar elíptica e pubescente, frutos depresso-obovoides com costas medianas inconspícuas, lenticelados, pubescentes e contém três a quatro sementes por fruto.
9. Aspidosperma quebracho-blanco Schltdl., Bot. Zeitung (Berlin) 19: 137. 1861. Fig. 2b,c Árvores, 5-15 m alt.; tronco cinzento a castanho; ritidoma suberoso, não lenticelado, fissurado com cristas agudas ou planas, interrompidas por fissuras transversais; látex incolor. Râmulos alternos, cinzentos, não suberosos, lenticelados, não fissurados, glabros. Filotaxia
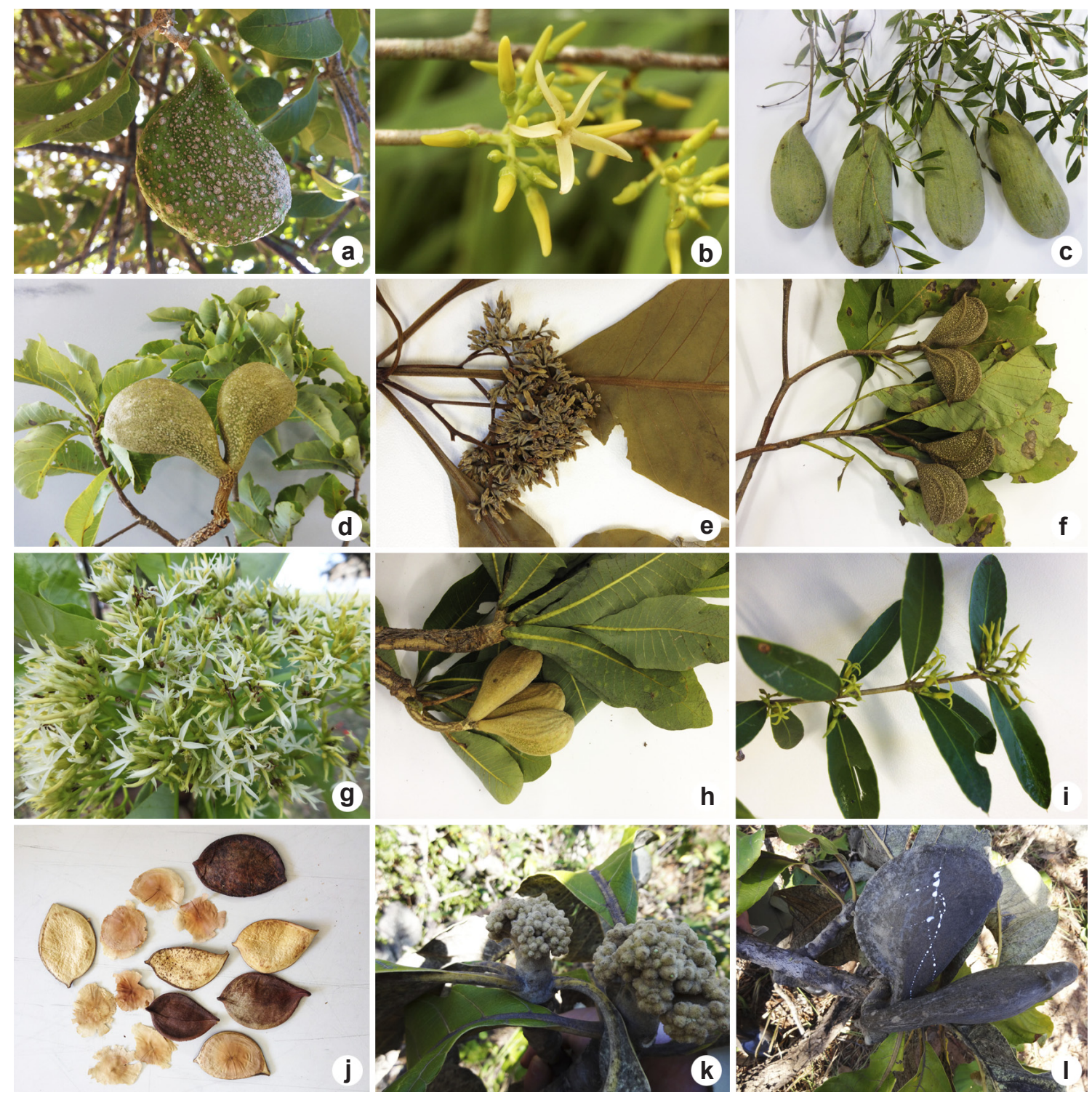

Figura 2 - a. Aspidosperma pyrifolium - fruto. b-c. A. quebracho-blanco - b. ramos com inflorescência (foto: A.O. Simões); c. ramos com frutos. d. A. quirandy - ramo com frutos. e-f. A. subincanum - e. inflorescência; f. ramos com frutos. g-h. A. tomentosum - g. inflorescência; h. ramos com frutos. i-j. A. triternatum - i. ramo com inflorescência; j. frutos com sementes. k-1. A. verbascifolium - k. ramo com inflorescência; 1. frutos.

Figure 2 - a. Aspidosperma pyrifolium - a. fruit. b-c. A. quebracho-blanco - b. inflorescence branch (photo: A.O. Simões); c. fruit branch. d. A. quirandy - fruit branch. e-f. A. subincanum - e. inflorescence; f. fruit branch. g-h. A. tomentosum - g. inflorescence; h. fruit branch. i-j. A. triternatum - i. inflorescence branch; j. fruit with seed. k-1. A. verbascifolium - k. inflorescence branch; 1. fruits. 
verticilada, pecíolos $0,12-0,42 \mathrm{~cm}$ compr., glabros; lâminas estreitamente elípticas 1,9-5 × $0,4-1,2 \mathrm{~cm}$, glabras, base cuneada a atenuada, ápice agudo com espinho pontiagudo, $0,1-0,2$ $\mathrm{cm}$ compr., venação craspedódroma, nervuras secundárias 15-22, nervuras terciárias impressas. Inflorescência dicásio, axilar ou terminal 0,9-2,2 cm compr. serícea ou glabrescente; pedúnculo $0,4-0,8 \mathrm{~cm}$ compr.; pedicelo $0,1-0,3 \mathrm{~cm}$ compr. Flores $0,6-1,6 \mathrm{~cm}$ compr., externamente glabras; lacínias do cálice $0,8-1 \mathrm{~mm}$ compr.; corola branca a amarelada; tubo 0,3-0,4 cm compr., diâmetro 0,03-0,08 cm, internamente seríceo, fendas no terço superior do tubo; lobos da corola $0,2-0,8 \times$ 0,03-0,06 cm, internamente glabros, oblongos, frequentemente dextrorsos; anteras $0,5-0,9 \mathrm{~mm}$ compr.; filete $0,1-0,2 \mathrm{~mm}$ compr.; ovário ovoide, 0,06-0,11 cm compr., glabro; estilete $0,4-0,8$ mm compr.; cabeça estilar $0,2-0,4 \mathrm{~mm}$ compr., oblonga, glabra. Folículos cinzentos, elipsoides, 6-9 × 4,6-6,4 cm, costas medianas presentes e nervuras costais ausentes, não mucronados, lenticelados, ásperos; pedúnculo 1-1,7 cm compr., fissurado, glabro. Sementes brancas a amareladas 23-26 por fruto, amplamente elípticas, 3,4-6,1 $\times$ 3,3-5,2 cm; núcleos oblados, 1,7-2,6 cm diâm., predominantemente excêntricos.

Material examinado selecionado: Porto Murtinho, Estrada principal para o Rio Amonguijá, 5.XII.2013, fl., M.A. Farinaccio et al. 980 (CGMS), Fazenda Anaí, 7.VI.2015, fr., D.J. Machate et al. 138 (CGMS).

Ocorre em Corumbá e Porto Murtinho, em solo argiloso entre 78-104 m de altitude, é considerada, juntamente com A. triternatum, indicadoras do Chaco. Com flores em agosto e dezembro e frutos em maio, junho, agosto e dezembro. Espécie criticamente em perigo (CR) pelos critérios A1(acd) e E (IUCN 2011).

Pode ser confundida com $A$. triternatum por apresentar flores muito semelhantes, folhas verticiladas e ápice com espinho pontiagudo. Porém, A. quebracho-blanco difere desta por apresentar 15 a 22 pares de nervuras secundárias, lobos da corola dextrorsos e folículos não mucronados. (versus 9 a 12 pares de nervuras secundárias, lobos da corola sinistrorsos e folículos mucronados em A. triternatum).

10. Aspidosperma quirandy Hassl., Repert. Spec. Nov. Regni Veg. 12: 259. $1913 . \quad$ Fig. 2d

Árvores ou arvoretas, 4-18 m alt.; tronco cinzento a castanho; ritidoma suberoso, não lenticelado, fissurado com cristas convexas, longitudinalmente descontínuas; látex branco.
Râmulos alternos, não suberosos, lenticelados, não fissurados, pubescentes a glabrescentes. Filotaxia alterna, pecíolos ou sésseis $0,2-1 \mathrm{~cm}$ compr., pubescentes ou glabrescentes; lâminas elípticas $9,7-10,4 \times 2,4-6,1 \mathrm{~cm}$, tomentosas a seríceas, base cuneada a atenuada, ápice cuneado a obtuso sem espinho, venação semi-craspedódroma, nervuras secundárias 14-25, nervuras terciárias impressas. Inflorescência pleiotirso, terminal 3-4,2 cm compr., tomentosa; pedúnculo $0,4-1 \mathrm{~cm}$ compr.; pedicelo $0,1-0,2 \mathrm{~cm}$ compr. Flores $0,6-0,8 \mathrm{~cm}$ compr., tomentosas; lacínias do cálice $0,2-0,3 \mathrm{~cm}$ compr., prefloração quincuncial; corola branca a amarelada; tubo $0,2-0,4 \mathrm{~cm}$ compr., diâmetro $0,1-0,2 \mathrm{~cm}$, fendas no terço superior do tubo; lobos da corola 0,5-0,6 $\times 0,1 \mathrm{~cm}$, internamente glabro, oblongos, sinistrorsos; anteras $0,8-1 \mathrm{~mm}$ compr.; filete $0,2-$ $0,3 \mathrm{~mm}$ compr.; ovário ovoide $0,6-0,7 \mathrm{~mm}$ compr., glabro; estilete $0,7-0,8 \mathrm{~mm}$ compr.; cabeça estilar 0,3-0,4 mm compr., globosa, glabra. Folículos cinzentos a acastanhados, depresso-ovoides 4,4-7,5 $\times 2,8-3,9 \mathrm{~cm}$, costas medianas presentes, nervuras costais ausentes, não mucronados, lenticelados, tomentosos ou glabrescentes; pedúnculo $2-4 \mathrm{~cm}$ compr., fissurado, glabro. Sementes castanhas 6-10 por fruto, elípticas a ovoides $3,1-3,8 \times 2,3-2,6 \mathrm{~cm}$; núcleos elípticos a ovados 2,1-2,4 × 1,8-1,9 cm diâm., predominantemente concêntricos.

Material examinado selecionado: Corumbá, Reserva Acurizal (Ecotrópico), próximo ao córrego Retiro, serra do Amolar, borda oeste do Pantanal, 18.IX.2001, fl., A. Pott et al. 9441 (CGMS); Porto Murtinho, Morro, ao longo da estrada para Rio Apa, 4.VI.2014, fr. D.J. Machate et al. 6 (CGMS).

Ocorre em Aquidauana, Bonito, Corumbá, Ladário e Porto Murtinho; na Floresta Estacional Decidual e Floresta Estacional Semidecidual Submontana, em solo litólico, calcário e arenoso, entre 93-400 m de altitude. Com flores em junho e setembro e frutos de janeiro a novembro. Espécie pouco preocupante (LC) (IUCN 2011).

Pode ser confundida com $A$. tomentosum por apresentar ritidoma suberoso, fissurado com cristas convexas e longitudinalmente descontínuas, folhas elípticas, ovário glabro, frutos depressoovoides com costas medianas e não mucronados. Porém, A. quirandy difere desta por exibir râmulos lenticelados, folhas com nervação semi-craspedódroma, inflorescência terminal, lobos da corola sinistrorsos e frutos sem costas medianas (versus râmulos não lenticelados, folhas com venação craspedódroma, inflorescência subterminal, lobos da corola dextrorsos e frutos com costas medianas em A. tomentosum). 
11. Aspidosperma subincanum Mart. ex A. DC., Prodr. 8: 397. 1844.

Fig. 2e,f

Árvores ou arvoretas, 3-12 m alt.; tronco cinzento a castanho, ritidoma não suberoso, não lenticelado, fissurado com cristas planas, interrompidas por fissuras transversais; látex branco. Râmulos alternos, não suberosos, lenticelados, não fissurados, pubescentes a glabrescentes. Filotaxia alterna, pecíolos 2-3 cm compr., glabros; lâminas elípticas a amplamente elípticas 13,4-18,2 × 5,3-12,3 cm, abaxialmente velutinas, adaxialmente glabras, base cuneada a obtusa, ápice cuneado a obtuso sem espinho, venação broquidódroma, nervuras secundárias 14-21, nervuras terciárias impressas. Inflorescência dicásio, terminal 2,7-4,1 cm compr., tomentosa; pedúnculo $2-3 \mathrm{~cm}$ compr.; pedicelo $0,1-0,7 \mathrm{~cm}$ compr. Flores $0,4-0,5 \mathrm{~cm}$ compr., tomentosas; lacínias do cálice $0,15-0,17 \mathrm{~cm}$ compr.; corola branca a amarelada; tubo 0,4-0,5 cm compr., diâmetro $0,1 \mathrm{~cm}$, fendas no terço inferior do tubo; lobos da corola $0,1-0,2 \times 0,7-0,9 \mathrm{~cm}$, internamente glabros, ovais, eretos; anteras $0,8-0,9$ mm compr.; filete $0,1-0,3 \mathrm{~mm}$ compr.; ovário ovoide $0,11-0,13 \mathrm{~cm}$ compr., tomentoso; estilete 0,2-0,5 mm compr.; cabeça estilar 0,17-0,22 mm compr., globosa, glabra. Folículos castanhos, depresso-ovoides 4,4-6,5 × 2-3,3 cm, costas medianas presentes, nervuras costais ausentes, mucronados, lenticelados, tomentosos; pedúnculo 4,2-5 cm compr., lenticelado, glabro. Sementes castanhas 3-5 por fruto, elípticas a amplamente elípticas 3,3-3,8 × 2,4-2,8 cm; núcleos elípticos 1,9-2,2 × 1,5-1,8 cm diâm., predominantemente concêntricos.

Material examinado selecionado: Campo Grande, Chácara Cambará, 27.VIII.1991, fl., C.A. Conceição 2779 (CGMS); Bodoquena, ao longo da estrada de Guaicurus junto a uma pequena pedreira, 14.VII.2014, fr., D.J. Machate et al. 11 (CGMS).

Ocorre em Bodoquena, Campo Grande, Corumbá, Ladário e Porto Murtinho, na Floresta Estacional Decidual e Floresta Estacional Semidecidual Submontana, em solo arenoso e litólico, entre 151-331 m de altitude. Com flores de agosto a novembro e frutos em abril, julho, setembro e novembro. Espécie pouco preocupante (LC) (IUCN 2011).

Aspidosperma subincanum é facilmente reconhecida por apresentar ritidoma fissurado com cristas planas e interrompido por fissuras transversais, pecíolos 2 a $3 \mathrm{~cm}$ de comprimento, folhas amplamente elípticas com venação broquidódroma, lobos da corola eretos, ovário tomentoso, folículos depresso-ovoides, com costas medianas, mucronados e contém 3 a 4 sementes por fruto.

12. Aspidosperma tomentosum Mart., Flora 7(1, Beil. 4): 135. 1824.

Fig. $2 \mathrm{~g}, \mathrm{~h}$

Árvores ou arvoretas, 4-12 m alt.; tronco cinzento; ritidoma suberoso, não lenticelado, fissurado com cristas convexas, longitudinalmente descontínuas; látex branco. Râmulos alternos, cinzentos a castanhos, suberosos, não lenticelados, fissurados longitudinalmente, tomentosos a glabrescentes. Filotaxia alterna, pecíolos ou sésseis 0,1-0,2 cm compr., tomentosos a glabrescentes; lâminas elípticas 9,9-26,7 ×4-12 cm, adaxialmente tomentosas, abaxialmente glabras, base decorrente a atenuada, ápice agudo a cuneado sem espinho, venação craspedódroma, nervuras secundárias 11-30, nervuras terciárias impressas. Inflorescência pleiotirso, subterminal 5,3-11,8 cm compr., tomentosa; pedúnculo 3,9-8,8 cm compr.; pedicelo 0,1-0,3 cm compr. Flores 0,7-1 cm compr., externamente tomentosas; lacínias do cálice 0,3-0,4 cm compr., internamente seríceos; corola branca a amarelada; tubo 0,36-0,43 cm compr., diâmetro 0,04-0,14 cm, internamente pubescente, fendas no terço inferior do tubo; lobos da corola 0,7-0,9 × 0,1 cm, oblongos, dextrorsos; anteras 0,7-0,8 mm compr.; filete 0,06-0,14 mm compr.; ovário ovoide $0,6-0,8 \mathrm{~cm}$ compr., glabro; estilete 0,07-0,13 cm compr.; cabeça estilar 0,5-0,8 mm compr., oblonga, glabra. Folículos castanhos a amarelados, depresso-ovoides 5,1-8,2 × 3,2-4,2 $\mathrm{cm}$, costas medianas e nervuras costais presentes, não mucronados, às vezes lenticelados, tomentosos, ásperos; pedúnculo 3,4-9,2 cm compr., fissurado, glabro. Sementes castanhas 5-9 por fruto, elípticas a circulares $3,1-4,3 \times 2,1-3,1 \mathrm{~cm}$; núcleos elípticos a circulares 1,2-2,1 × 1-1,8 cm diâm., predominantemente excêntricos.

Material examinado: Campo Grande, RPPN-UFMS, 26.IV.2014, fr, D.J. Machate et al. 1 (CGMS); em frente da CCBS-UFMS, 8.IX.2014, fl. e fr., D.J. Machate \& F.F. Júnio 41 (CGMS).

Ocorre em Campo Grande, Corumbá, Jaraguari, Miranda, Ribas do Rio Pardo, Rio Verde do Mato Grosso; no Cerrado, em solo arenoso, entre 255-460 m de altitude. Com flores em setembro e frutos de abril a setembro. Espécie pouco preocupante (LC) (IUCN 2011).

Pode ser confundida com A. quirandy por apresentar ritidoma suberoso, fissurado com cristas convexas e longitudinalmente descontínuas, folhas 
elípticas, ovário glabro, frutos depresso-ovoides com costas medianas e não mucronados. Porém, A. tomentosum difere desta por exibir râmulos não lenticelados, folhas com venação craspedódroma, inflorescência subterminal, lobos da corola dextrorsos e frutos com costas medianas (versus râmulos lenticelados, folhas com nervação semicraspedódroma, inflorescência terminal, lobos da corola sinistrorsos e frutos sem costas medianas em A. quirandy).

13. Aspidosperma triternatum Rojas Acosta, Essai Therap. Veg. Corrientes 21. 1913.

Fig. 2i,j

Árvores ou arvoretas, $4-8 \mathrm{~m}$ alt.; tronco castanho; ritidoma não suberoso, não lenticelado, não fissurado; látex incolor. Râmulos alternos, cinzentos a castanhos, não suberosos, não lenticelados, não fissurados, pubescentes a glabrescentes. Filotaxia verticilada, pecíolos $0,07-0,08 \mathrm{~cm}$ compr., glabros; lâminas estreitamente elípticas 3,1-3,5 × 0,8-1,1 $\mathrm{cm}$, glabras, base cuneada a atenuada, ápice agudo com espinho pontiagudo, $0,07-0,13 \mathrm{~cm}$ compr., venação craspedódroma, nervuras secundárias 9-12 pares, nervuras terciárias impressas. Inflorescência dicásio, axilar ou terminal $0,8-1,1 \mathrm{~cm}$ compr., pubescente ou glabrescente; pedúnculo $0,1-0,3 \mathrm{~cm}$ compr.; pedicelo $0,1-0,2 \mathrm{~cm}$ compr. Flores $0,1-0,6$ cm compr., glabras; lacínias do cálice $0,1-0,2 \mathrm{~cm}$ compr.; corola branca a amarelada; tubo $0,1-0,3$ cm compr., diâmetro 0,06-0,13 cm, internamente seríceo, fendas no terço inferior do tubo; lobos da corola $0,2-0,4 \times 0,04-0,07 \mathrm{~cm}$, internamente glabros, oblongos, frequentemente sinistrorsos; anteras $0,08-0,1 \mathrm{~cm}$ compr.; filete $0,03-0,1 \mathrm{~mm}$ compr.; ovário ovoide $0,4-0,6 \mathrm{~mm}$ compr., glabro; estilete $0,1-0,8 \mathrm{~mm}$ compr.; cabeça estilar $0,2-0,3$ mm compr., oblonga, glabra. Folículos castanhos, elipsoides 4,7-5,4 × 2,4-3,6 cm, costas medianas e nervuras costais presentes, mucronados, não lenticelados, glabros; pedúnculo $0,8-1,1 \mathrm{~cm}$ compr., não lenticelado, glabro. Sementes castanhas 6-12 por fruto, amplamente elípticas 3,4-3,6 $\times$ 3,2-3,4 cm; núcleos oblados $1-1,4 \mathrm{~cm}$ diâm., predominantemente excêntricos.

Material examinado selecionado: Porto Murtinho, Hotel dos Camalotes, 2.VI.2014, fl., D.J. Machate et al. 2 (CGMS); Corumbá, Fazenda Coqueiro, 18.XI.1989, fr., A. Pott 5293 (CPAP).

Ocorre em Corumbá e Porto Murtinho; indicador do Chaco, juntamente com A. quebrachoblanco, encontra-se principalmente em terrenos baixos com solo argiloso, entre $98-119 \mathrm{~m}$ de altitude. Com flores em março, abril e junho e frutos em novembro e dezembro. Espécie está na situação de baixo risco (LR). Porém propomos que para área de estudo seja considerada espécie criticamente em perigo (CR) pelos critérios $\mathrm{A} 1$ (acd) e D (IUCN 2011).

Pode ser confundida com A. quebrachoblanco por apresentar folhas verticiladas e ápice com espinho pontiagudo e exibem flores muito semelhantes. Porém, A. triternatum difere desta por apresentar 9 a 12 pares de nervuras secundárias, lobos da corola sinistrorsos e folículos mucronados (versus 15 a 22 pares de nervuras secundárias, lobos da corola dextrorsos e folículos não mucronados em A. quebracho-blanco).

14. Aspidosperma verbascifolium Müll. Arg., Fl. Bras. 6(1): 46. 1860.

Fig. $2 \mathrm{k}, 1$

Árvores ou arvoretas, 3-7 m alt.; tronco cinzento; ritidoma suberoso, não lenticelado, fissurado com cristas convexas ou agudas, longitudinalmente descontínuas; látex branco. Râmulos alternos, cinzentos a amarelos, suberosos, não lenticelados, fissurados longitudinalmente, tomentosos a glabrescentes. Filotaxia alterna, pecíolos 1-4 cm compr., glabros; lâminas elípticas a ovais $19-35,2 \times 9,3-19,5 \mathrm{~cm}$, abaxialmente glabras, adaxialmente tomentosas, base cuneada assimétrica, ápice cuneado a obtuso sem espinho, venação craspedódroma, base da nervura central pubescente ou glabrescente, nervuras secundárias 11-17, nervuras terciárias impressas. Inflorescência pleiocásio, axilar ou terminal 1,7-5,7 cm compr., tomentosa; pedúnculo $0,5-3 \mathrm{~cm}$ compr.; pedicelo $0,2-0,6 \mathrm{~cm}$ compr. Flores $1-2,2 \mathrm{~cm}$ compr., externamente glabras, internamente tomentosas; lacínias do cálice $0,5-0,9 \mathrm{~cm}$ comp.; corola branca a amarelada, tubo 1,4-1,9 cm compr., diâmetro $0,2-0,4 \mathrm{~cm}$, fendas no terço inferior do tubo; lobos da corola $0,5-1,4 \times 0,2 \mathrm{~cm}$, ovados a oblongos, eretos; anteras $0,19-0,22 \mathrm{~cm}$ compr.; filete $0,2-0,7 \mathrm{~mm}$ compr.; ovário ovoide $0,3-0,5$ cm compr., glabro; estilete $0,1-0,2 \mathrm{~cm}$ compr.; cabeça estilar 0,8-0,9 mm compr., oblonga, glabra. Folículos cinzentos a acastanhados, depressoovoides 14,6-20 × 7,8-11,4 cm, costas medianas e nervuras costais ausentes, mucronados, não lenticelados, tomentosos; pedúnculo $2,9-3,9 \mathrm{~cm}$ compr., fissurado, tomentoso. Sementes brancas a amareladas 20-22 por fruto, amplamente elípticas a circulares 7,7-9,3 × 5,9-8 cm; núcleos amplamente elípticos a circulares 4,5-6,2 × 4,1-5,7 cm de diâm., predominantemente excêntricos. 
Material examinado selecionado: Ribas do Rio Pardo, ao longo da BR 262, 19.VIII.2014, fl. e fr., D.J. Machate et al. 32 (CGMS).

Ocorre em Campo Grande, Rio Verde de Mato Grosso, Corguinho e Ribas do Rio Pardo; no Cerrado, em solo arenoso, entre 256-535 m de altitude. Com flores em agosto e outubro, com frutos em agosto. Espécie vulnerável (VU) pelos critérios A1(acd) e D2 (IUCN 2011).

Pode ser confundida com $A$. macrocarpon por apresentar frutos cinzentos, depressoovoides, costas medianas e nervuras costais ausentes, não lenticelados e tomentosos. Porém, A. verbascifolium difere desta por exibir râmulos suberosos, lâminas foliares maiores ou iguais a $19 \mathrm{~cm}$ de comprimento e ovário glabro (versus râmulos não suberosos, lâminas foliares menores ou iguais a $18 \mathrm{~cm}$ de comprimento e ovário velutino em A. tomentosum). Vale a pena destacar que essas espécies apresentam os maiores frutos no gênero com 12 a $20 \mathrm{~cm}$ de comprimento.

\section{Agradecimentos}

Os autores agradecem ao Laboratório de Botânica da UFMS, e aos curadores dos herbários visitados COR, CPAP, MBM e UEC. À Profa. Dra Ângela Lúcia Bagnatori Sartori, coordenadora do Projeto Casadinho/Procad, e ao Prof. Dr. Arnildo Pott, a correção do abstract. Ao Prof. Dr. André Olmos Simões, ao Dr. Washington Marcondes Ferreira, ao Dr. Marcelo Pace, e a João Roberto Fabri, o apoio e facilidades oferecidas. Aos revisores anônimos, as valiosas contribuições. Aos editores e revisores, as sugestões. Ao Conselho de Desenvolvimento Nacional de Pesquisa (CNPq), e à Fundação de Apoio ao Desenvolvimento do Ensino, Ciência e Tecnologia do estado de Mato Grosso do Sul (FUNDECT), as bolsas concedidas.

\section{Referências}

Alves, F.M.; Lehn, C.R.; Damasceno-Jr, G.A.; Sartori, A.L.B.; Pott, A.; Pott, V.J.; Bortolotto, I.M.; Ishii, I.H.; Salis, S.M.; Urbanetz, C.; Bueno, M.L. \& Sciamarelli, A. (em prelo) Coleções botânicas do estado de Mato Grosso do Sul: situação atual e perspectivas. Iheringia, série Botânica.

BFG. 2015. Growing knowledge: an overview of Seed Plant diversity in Brazil. Rodriguésia 66: 1085-1113.

De Candolle, A. 1844. Prodromus Systematis Naturalis Regni Vegetabilis. Sumptibus Fortin, Masson et Sociorum, Parisiis. Pp. 396-399.

Dubs, B. 1998. Prodromus florae Matogrossensis. Part 1. Checklist of angiosperms. Vol. 3. The botany of Mato Grosso. Betrona verlag, Küssnacht. Pp. 18-22.
Endress, M.E.; Liede-Schumann, S. \& Meve, U. 2014. An updated classification for Apocynaceae. Phytotaxa 159: 175-194.

Font Quer, P. 1985. Dicionário de Botânica. Labor, Barcelona. 1244p.

Gonçalves, E.G. \& Lorenzi, H. 2011. Morfologia vegetal: organografia e dicionário ilustrado de morfologia das plantas vasculares $2^{\mathrm{a}}$ ed. Instituto Plantarum de estudos da flora, São Paulo. 512p.

Hassler, E. 1913. Ex herbario hassleriano: Novitates paraguarieses XVIII. In: Feddle, P.F. (ed.). Vol. 12. Repertorium specierum novarum regni vegetabilis, Berlin. Pp. 257-263.

IBGE - Fundação Instituto Brasileiro de Geografia e Estatística. 1992. Manual técnico da vegetação brasileira: departamento de recursos naturais e estudos ambientais, Rio de Janeiro. 92p.

IUCN Standards and Petitions Subcommittee. 2011. Guidelines for using the IUCN red list categories and criteria. Version 9.0. Disponível em <http:// www.inecc.gob.mx/descargas/dgioece/2011 sem lista roja auaron art $04 \mathrm{rlg}$.pdf $>$. Acesso em 19 fevereiro 2016.

Koch, I. \& Kinoshita, L.S. 1999. As Apocynaceae s. str. da região de Bauru, São Paulo, Brasil. Acta botanica brasilica 13: 61-86.

Koch, I. 2013. Aspidosperma Mart. Flora de Sergipe In: Prata, A.P.N.; Amaral, M.C.E.; Farias, M.C.V. \& Alves, M.V. (eds.). Vol. 1. Gráfica e Editora Triunfo Ltda., Aracaju. Pp. 52-54.

Lorenzi, H. 1992. Árvores Brasileiras: manual de identificação e cultivo de plantas arbóreas nativas do Brasil. Editora Plantarum, Nova Odessa. 352p.

Lorenzi, H. 1998. Árvores brasileiras: manual de identificação e cultivo de plantas arbóreas nativas do Brasil. $2^{\mathrm{a}}$ ed. Editora Plantarum, Nova Odessa. 352p.

Marcondes-Ferreira, W. \& Kinoshita, L.S. 1996. Uma nova divisão infragenérica para Aspidosperma Mart. (Apocynaceae). Revista Brasileira de Botânica 19: 203-214.

Marcondes-Ferreira, W. 2005. Aspidosperma Mart. In: Wanderley, M.G.L.; Shepherd, G.J.; Melhem, T.S.; Martins, S.E.; Kirizawa, M. \& Giulietti. A.M. (eds.). Flora Fanerogâmica do estado de São Paulo. Instituto de Botânica, São Paulo. Vol. 4, pp. 39-47.

Martius, C.F.P. 1824a. Vierte Beilage Zur Flora oder botanischen Zeitung 7: 135-136.

Martius, C.F.P. 1824b. Nova Genera et Species Plantarum, Brasiliensium. Monachii 21: 57-60.

Morokawa, R.; Simões, A.O. \& Kinoshita, L.S. 2013 Apocynaceae do Parque Nacional da Serra da Canastra, Minas Gerais, Brasil. Rodriguésia 64: 179-199.

Müller, A.J. 1860. Apocynaceae. In: Martius, C.F.P. \& Eichler, A.G. (eds.). Flora Brasiliensis. Frid. Fleisher, Lipsiae. Vol. 6, pars I, pp. 43-61.

Pereira, M.M.; Jácome, R.L.R.P.; Alcântara, A.F.C.; Alves, R.B. \& Raslan, D.S. 2007. Alcalóides indólicos 
isolados de espécies do gênero Aspidosperma (Apocynaceae). Química Nova 30: 970-983.

Peel, M.C.; Finlayson, B.L. \& McMahon T.A. 2007. Updated world map of the Koppen-Geiger climate classification. Hydrology and Earth System Sciences 11: 1633-1644.

Radford, A.E.; Dickison, W.C.; Massey, J.R. \& Bell, C.R. 1974. Vascular Plants Systematics. Pp. 95142.

Rapini, A. 2012. Taxonomy "under construction": advances in the systematics of Apocynaceae, with emphasis on the Brazilian Asclepiadoideae. Rodriguésia 63: 75-88.

Ribeiro, J.E.L.S.; Hopkins, M.J.G.; Vicentini, A.; Sothers, C.A.; Costa, M.A.S.; Brito, J.M.;
Souza, M.A.D.; Martins, L.H.P.; Lohmann, L.G.; Assunção, P.A.C.L.; Pereira, E.C.; Silva, C.F.; Mesquita, M.R \& Procópio, L.C. 1999. Flora da reserva Ducke: guia de identificação das plantas vasculares de uma floresta de terra-firme na Amazônia Central. INPA-DFID, Manaus. 816p.

Thiers, B. [continuously updated]. Index Herbariorum: A global directory of public herbaria and associated staff. New York Botanical Garden's Virtual Herbarium. Disponível em $<$ http://sweetgum.nybg. org/science/ih/>. Acesso em 19 fevereiro 2016.

Woodson-Jr, R.E. 1951. Studies in the Apocynaceae VIII. An interim revision of the genus Aspidosperma Mart. \& Zucc. Annals of the Missouri Botany Garden 38: 118-207.

Lista de exsicatas

Almeida et al. 139, 184 CPAP, ESA(8). Alves 573 ESA(10). Assunção 612, 704 CGMS(2). Battilani 58 CGMS(6). Battilani 91 CGMS(1). Benites-Silva et al. 1 COR(2). Bernardi et al. 18287 MBM(6). Bernardi 205668 MBM(7). Bezerra et al. 103, 122 CGMS(2). Bezerra et al. 112, 121 COR(2). Blattilani 91 CGMS(1). Bueno et al. 31 CGMS(10). Bueno et al. 34 COR(8). Caxambu et al. 3904 CGMS(7). Conceição 1271 COR(2). Conceição 2071 CGMS, COR(12). Conceição 2166 MBM(6). Conceição 2779, 2875 CGMS(11). Costa et al. 21841 BHCB, MBM(7). Damasceno-Jr. et al. 1614, 2554, 2938 CGMS, COR(3). Damasceno-Jr. et al. 1867 COR(8). Damasceno-Jr. et al. 2021, 2821 CGMS(11). Damasceno-Jr. et al. 2142, 2382, 2893, 3692 CGMS, COR(10). Damasceno-Jr. et al. 3147, 3798 CGMS, COR, UEC(11). Damasceno-Jr. 3641 CGMS, UEC(11). Duarte 5286 MBM(6). Farinaccio et al. 971, 980, 981, 985, 988, 992, 993 CGMS(9). Farinaccio 1013, 1015 CGMS(9). Farinaccio 1016 CGMS(13). Garcia 13836 UEC(7). Gris et al. 85 CGMS(14). Guimarães 1269 R(12). Guimarães 1298 RB(2). Hatschbach 24637, 32355, 66562 MBM(4). Hatschbach et al. 60812 MBM, NY(8). Hatschbach et al. 69122 MBM(6). Hatschbach et al. 73950 MBM, RUSU(1). Hatschbach et al. 74090 RUSU, RB(11). Janaina 8 CGMS(4). Jesus et al. 190 CPAP(3). Koch et al. 118 UEC(7). Laicia et al. 4 CGMS(4). Lima et al. 134 CGMS(9). Lima et al. 179 RB, UEC(12). Lupinetti 2 CGMS(9). Jesus et al. 190 CPAP(3). Machado 11 CGMS(2). Machado 23 CGMS(11). Machate et al. 1, 8, 10, 19, 21, 22, 33, 36, 140 CGMS(12). Machate et al. 2, 107 CGMS(13). Machate et al. 3, 5, 23, 24, 25, 26, 27, 28, 29, 30, 31, 46, 47, 48 CGMS(1). Machate et al. 4, 137, 138 CGMS(9). Machate et al. 6, 44, 45 CGMS(10). Machate et al. 11, 12, 13, 18, 123 CGMS(11). Machate et al. 32, 34, 35, 37, 141, 143 CGMS(14). Machate \& Júnio 39, 41 CGMS(12). Machate \& Júnio 40 CGMS(5). Machate \& Júnio 42, 43 CGMS(4). Machate 49, 50, 78 CGMS(5). Machate et al. 75, 76, 117, 121, 139 CGMS(5). Machate \& Graziela 77 CGMS(10). Machate 105 CGMS(4). Machate \& Fabri 122, 124, 126 CGMS(10). Machate \& Fabri 128, 130 CGMS(12). Machate \& Fabri 123, 127, 131, 132, 148 CGMS(11). Machate \& Fabri 125 CGMS(8). Machate \& Fabri 128, 130 CGMS(12). Machate \& Fabri 129 CGMS(5). Machate \& Marcondes-Ferreira 133 CGMS(3). Machate \& Marcondes-Ferreira 134, 136 CGMS(6). Machate \& Marcondes-Ferreira 135 CGMS(8). Machate et al. 138 CGMS(9). Machate et al. 142, 151 CGMS(8). Machate \& Fabri 144, 145, 146, 147 CGMS(2). Machate \& Sinani 149 CGMS(4). Magalhães et al. 429 UEC(2). Malme 2745 UEC, G(2). Oliveira et al. 155 COR(8). Paula 1542 COR, R(2). Pires et al. 17344 RB(13). Planurb 143 CGMS (7). Pott 5293, 6833 CPAP(13). Pott et al. 8514 CGMS(11). Pott et al. 8615, 8787, 9441, 9485 CGMS(10). Pott 8860 CGMS(13). Pott et al. 9956, 11366, 13091 CGMS(2). Pott et al. 10650 CGMS(11). Pott 11842 CGMS(4). Pott et al. 12934 CGMS(9). Ramos 8 COR(10). Ratter et al. 2606, 6062 COR(2). Ratter et al. 5119 K(10). Ratter et al. 5129 K(8). Ratter et al. 5142 K(11). Ratter et al. 6074 COR, K(2). Resende et al. 125 COR(5). Resende et al. 875 CGMS(6). Resende et al. 1144 CGMS(4). Resende 6858 CGMS(6). Ribas 3226 COR(7). Rivaben 38 CGMS(14). Sabóia 28 CGMS(11). Salvador et al. 28 CGMS(6). Santos et al. 2871 CGMS(7). Sartori 115, 1087 CGMS(13). Sartori et al. 1020 CGMS(9). Sciamarelli et al. 997 CGMS(4). Seleme 100 CGMS(4). Seleme et al. 181 CGMS(13). Silva 829 MBM(10). Silva et al. 4358 COR(7). Steyermark et al. 122902 MBM(7). Takahasi 721 COR(8). Vicente 2 CGMS(9). Zacharias et al. 146 CGMS(11). Zacharias et al. 186 CGMS(3). Zacharias et al. 360 CGMS(10). 